\title{
G Antigen 2D
}

National Cancer Institute

\section{Source}

National Cancer Institute. GAntigen 2D. NCI Thesaurus. Code C104469.

G antigen 2D (116 aa, $\sim 13 \mathrm{kDa}$ ) is encoded by both the human GAGE2D and GAGE8 genes. This protein may be involved in tumor antigenicity. 